\title{
Pearls \& Oy-sters: Family history of Huntington disease disguised a case of dentatorubral-pallidoluysian atrophy
}

\author{
Sinem Tunc, MD,* Vera Tadic, MD,* Christine Zühlke, PhD, Yorck Hellenbroich, MD,
} and Norbert Brüggemann, MD

Neurology ${ }^{\circledR}$ 2018;90:142-143. doi:10.1212/WNL.0000000000004833

\section{Pearls}

- Additional neurologic signs such as mild cerebellar ataxia and uncommon EEG and MRI findings in patients with generalized chorea and a positive family history should prompt clinicians to also consider Huntington disease-like syndromes.

\section{Oy-sters}

- A self-reported positive family history for Huntington disease may disguise dentatorubralpallidoluysian atrophy, an autosomal dominantly inherited trinucleotide repeat expansion disorder that is very rare outside of Asian countries.

- Mild to moderate cerebellar ataxia may be overlooked in the presence of dominating generalized chorea.

\section{Case report}

A 42-year-old woman of Caucasian ancestry presented with an episode of acute paranoid psychosis, an 8-month history of slowly progressive generalized choreoathetosis, gait and speech disturbance, as well as cognitive impairment. Her choreoathetosis remarkably improved due to olanzapine, and subsequently, cerebellar signs became obvious upon neurologic examination (video, http://links.lww.com/WNL/A45). Cranial MRI revealed moderate atrophy of the vermal part of the cerebellum but not of the caudate nucleus. EEG showed runs of frontal intermittent high-amplitude delta activity. The patient reported a positive family history for Huntington disease (HD) (figure). Genetic testing was negative twice for HD and spinocerebellar ataxias (SCAs) including SCA17, but revealed 59 \pm 2 CAG repeats $(<48)$ in the ATN1 gene confirming the first German case of adult-onset dentatorubral-pallidoluysian atrophy (DRPLA). ${ }^{1,2}$

\section{Discussion}

The differential diagnosis of choreatic movement disorders can be challenging. At first sight, the presence of characteristic clinical signs such as adult-onset progressive generalized choreoathetosis and the combination with neuropsychiatric features may prompt clinicians to order a genetic test for HD. ${ }^{3}$ This is particularly true for patients where the family history for HD is reported to be positive. Nevertheless, this seemingly obvious diagnosis sometimes may be misleading. We report a case of DRPLA where the correct diagnosis was initially concealed by a positive family history of HD. Further, cerebellar ataxia as an unusual clinical sign for HD was not initially identified and only noticed when choreoathetosis improved following neuroleptic treatment. After our patient was tested negative twice for a repeat expansion in Huntingtin, further genetic testing for HD-like syndromes revealed $59 \pm 2$ CAG repeats in the ATN1 gene, confirming the correct genetic diagnosis. Retrospectively, the reported HD-positive family members happened to be diagnosed with HD before genetic testing was available-highlighting DRPLA as a differential diagnosis, also in populations where it was not described before.
Correspondence

Dr. Brüggemann

norbert.brueggemann@

neuro.uni-luebeck.de

MORE ONLINE

- Video

links.lww.com/WNL/A45

*These authors contributed equally to this work.

From the Institute of Neurogenetics (S.T., V.T., N.B.), Department of Neurology (S.T., V.T., N.B.), and Institute of Human Genetics (C.Z., Y.H.), University of Lübeck, Germany. Go to Neurology.org/N for full disclosures. Funding information and disclosures deemed relevant by the authors, if any, are provided at the end of the article. 

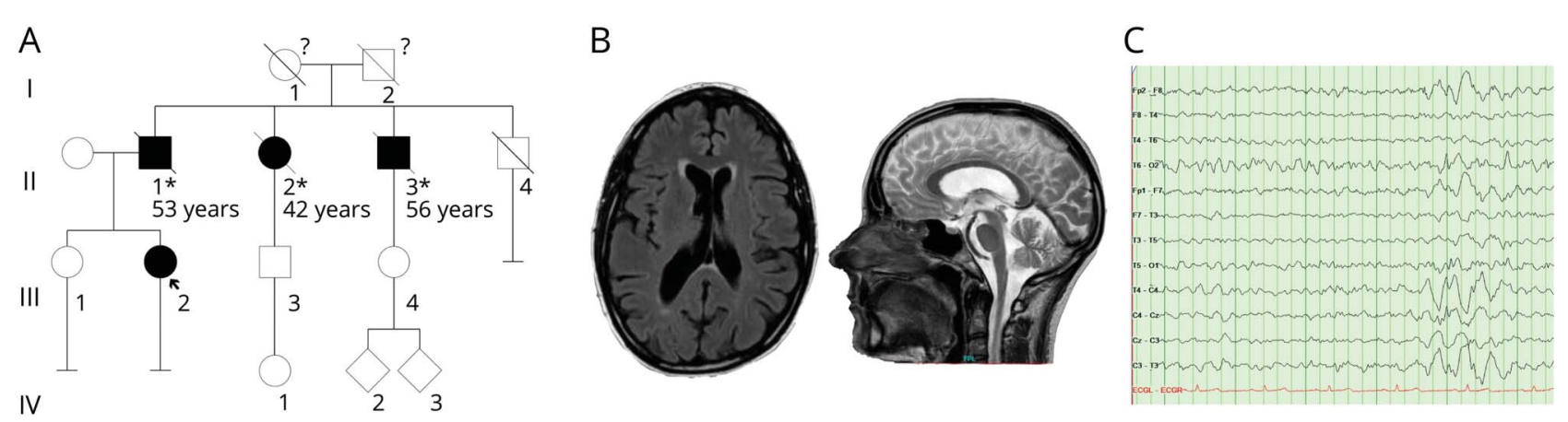

Pedigree of the family (A), MRI (B), and routine EEG (C) of the index patient. Arrow = index patient (ATN1 mutation); * affected individuals; (?) = clinical status unknown. MRI reveals moderate atrophy of the vermal part of the cerebellum but not of the caudate nucleus. EEG shows runs of frontal intermittent high-amplitude delta activity.

DRPLA is caused by an autosomal dominantly inherited pathogenic CAG trinucleotide expansion in the ATN1 gene. ${ }^{1,2}$ The CAG repeat length is normal in the range between 6 and 35, while the full penetrance is reported for $\geq 48 \mathrm{CAG}$ repeats. The size of the expanded ATN1 CAG repeat and the age at onset show an inverse correlation. Moreover, the clinical phenotype may vary dependent on repeat length and age at onset. ${ }^{2,4}$ Progressive ataxia and cognitive impairment are the most commonly reported features in all patients, while epilepsy and myoclonus are predominantly found in children, and choreoathetosis and dementia in adults. ${ }^{4}$ Progressive myoclonus epilepsy occurs usually in patients with an age at onset lower than 20 years. ${ }^{4}$ In individuals with an age at onset of 20 years and above, predominant features include choreoathetosis, dementia, and psychiatric disturbances such as psychosis. ${ }^{5}$ The total mean age at onset is 31.5 years, ranging from less than 12 months to 72 years. ${ }^{2}$ DRPLA has initially been reported to occur predominantly in Japan with a prevalence of $0.48: 100,000$, but several families of non-Asian ancestry have been identified, including North and South American, African American, and European populations. ${ }^{2}$ Analyses of the haplotype associated with DRPLA showed similarities between the Japanese and Portuguese haplotype, suggesting a founder effect. ${ }^{2}$

Brain imaging in DRPLA revealed a distinct atrophy of the brainstem and the cerebellum depending on the CAG repeat length. ${ }^{6}$ This pattern is different from $\mathrm{HD}$, in which the striatum is early and usually predominantly involved. ${ }^{7}$

DRPLA is an important differential diagnosis in individuals with adult-onset progressive ataxia, choreoathetosis, or dementia, even if the patients are of non-Asian ancestry and report a positive family history for other genetically inherited neurodegenerative disorders.

\section{Author contributions}

Sinem Tunc: acquisition and interpretation of data, drafting the manuscript. Vera Tadic: acquisition and interpretation of data, drafting the manuscript. Christine Zühlke: interpretation of data, critical revision of manuscript for intellectual content. Yorck Hellenbroich: interpretation of data, critical revision of manuscript for intellectual content. Norbert Brüggemann: study concept and design, interpretation of data, critical revision of manuscript for intellectual content.

\section{Study funding}

No targeted funding reported.

\section{Disclosure}

S. Tunc is supported by Deutsche Forschungsgemeinschaft (DFG; SFB 936/project C5) and the European Union's HORIZON 2020 research and innovation program under grant agreement 668738 . She received travel grants from the Movement Disorders Society and from Merz and Actelion Pharmaceuticals. V. Tadic is supported by Deutsche Forschungsgemeinschaft (DFG; SFB 936/project C5). She received travel grants from Actelion Pharmaceuticals and St. Jude Medical. C. Zühlke and Y. Hellenbroich report no disclosures relevant to the manuscript. N. Brüggemann is funded by the German Research Foundation (BR 4328/2-1) and the Collaborative Center for X-linked Dystonia-Parkinsonism. He received travel grants from Merz and St. Jude Medical. Go to Neurology.org/ $\mathrm{N}$ for full disclosures.

\section{References}

1. Koide $\mathrm{R}$, Ikeuchi $\mathrm{T}$, Onodera $\mathrm{O}$, et al. Unstable expansion of CAG repeat in hereditary dentatorubral-pallidoluysian atrophy (DRPLA). Nat Genet 1994;6:9-13.

2. Veneziano L, Frontali M. DRPLA. In: Pagon RA, Adam MP, Ardinger HH, et al, eds. GeneReviews. Seattle: University of Washington; 1999.

3. Warby SC, Graham RK, Hayden MR. Huntington disease. In: Pagon RA, Adam MP, Ardinger HH, et al, eds. GeneReviews. Seattle: University of Washington; 1993.

4. Tsuji S. Dentatorubral-pallidoluysian atrophy. Handb Clin Neurol 2012;103: 587-594.

5. Adachi N, Arima K, Asada T, et al. Dentatorubral-pallidoluysian atrophy (DRPLA) presenting with psychosis. J Neuropsychiatry Clin Neurosci 2001;13:258-260.

6. Koide R, Onodera O, Ikeuchi T, et al. Atrophy of the cerebellum and brainstem in dentatorubral pallidoluysian atrophy: influence of CAG repeat size on MRI findings. Neurology 1997;49:1605-1612.

7. Aylward EH, Sparks BF, Field KM, et al. Onset and rate of striatal atrophy in pre clinical Huntington disease. Neurology 2004;63:66-72. 


\section{Neurology}

\section{Pearls \& Oy-sters: Family history of Huntington disease disguised a case of dentatorubral-pallidoluysian atrophy}

Sinem Tunc, Vera Tadic, Christine Zühlke, et al.

Neurology 2018;90;142-143

DOI 10.1212/WNL.0000000000004833

\section{This information is current as of January 15, 2018}

\section{Updated Information \&} Services

References

Subspecialty Collections

Permissions \& Licensing

Reprints including high resolution figures, can be found at: http://n.neurology.org/content/90/3/142.full

This article cites 5 articles, 2 of which you can access for free at: http://n.neurology.org/content/90/3/142.full\#ref-list-1

This article, along with others on similar topics, appears in the following collection(s):

\section{Chorea}

http://n.neurology.org/cgi/collection/chorea

Gait disorders/ataxia

http://n.neurology.org/cgi/collection/gait_disorders_ataxia

Huntington's disease

http://n.neurology.org/cgi/collection/huntingtons_disease

\section{Psychosis}

http://n.neurology.org/cgi/collection/psychosis

Information about reproducing this article in parts (figures,tables) or in its entirety can be found online at:

http://www.neurology.org/about/about_the_journal\#permissions

Information about ordering reprints can be found online:

http://n.neurology.org/subscribers/advertise

Neurology ${ }^{\circledR}$ is the official journal of the American Academy of Neurology. Published continuously since 1951 , it is now a weekly with 48 issues per year. Copyright Copyright @ 2018 American Academy of Neurology. All rights reserved. Print ISSN: 0028-3878. Online ISSN: 1526-632X.

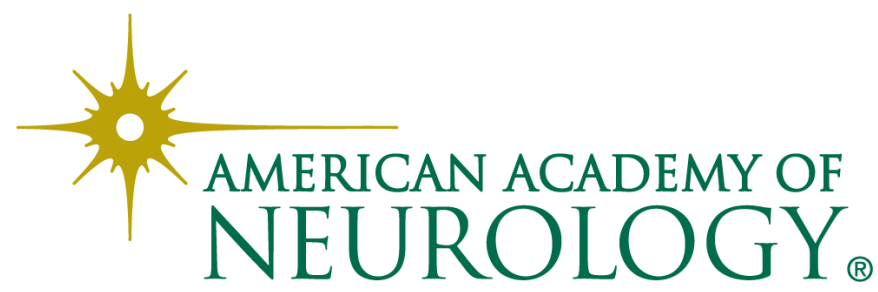

